\title{
The Impact of Foreign Direct Investments (FDls) on Economic Growth: The Solow Model in the Case of Albania
}

\author{
Llesh LLESHAJ \\ PhD candidate, Department of Finance, Faculty of Economy, University of Tirana,
}

lleshlleshaj@feut.edu.al

Arben MALAJ

Prof. Dr. , Lecturer, Department of Economics, Faculty of Economy, University of Tirana,

arben.malaj@gmail.com

\begin{abstract}
In the developing countries, including Albania, attracting FDIs remains a government priority towards development of investments and the whole economy. Therefore, the main objective of this paper is to analyze the impact of FDls on economic growth (GDP level) in Albania. The analysis is based on the neoclassical growth model, following the Solow model. The dependent variable in the model is the GDP level and independent variables are: capital (foreign and domestic capital investments) and labor (average salary) for the period 1996-2013 with quarterly data. The results of the econometric analysis indicate that the Solow model is applicable in the Albanian economy, showing a positive correlation which is statistically significant between the explanatory variables and the dependent variable both in the short and long run. The impact of FDIs on GDP is several times smaller than the impact of domestic capital investments. This elasticity can be explained by the lower level of FDI inflows compared to the domestic capital investments and the limitations in evaluating the "endogenous" growth of FDIs. Whereas the analysis of the sector and country of origin concentration of the FDI stock is done using the Herfindal - Hirschman index for the period 2007-2013 and the results determine a significant concentration of FDI stock, based on three sectors and a few countries of origin.
\end{abstract}

Keywords: FDIs in Albania, Solow growth model, Herfindal - Hirshman index.

JEL classification: C33 and C51

\section{A. Introduction and literature review}

With the development of globalization, the world has begun significantly to emphasize the importance of FDl's. The main priority in the agenda of governments in developing countries, it is the development of appropriate infrastructure to attract foreign direct investment (FDI). In order for the movement of capital flows from one country to another (leading to the creation of FDI), the host country with the country of origin must be in competitive positions with each other, resulting from the many advantages that the host country offers to investors from the country of origin. It is only through the competitive advantages in business, the host country is prone to absorb foreign investments and as a result, the latter in terms of competitiveness, offer more efficient production in a multitude of economic dimensions.

FDI influence significantly in the growth of investment capital in the host country, the transfer of new technologies and their technical knowledge into practice, there by: increasing the quality of their employees, bringing a distribution and productivity growth in the economy, enhancing the level of competitiveness and improving exports, etc. On the other hand, what it is of particular economic importance, is that FDI flows do not have any influential aspect in the debt or creation of debt in an economy; they are seen also as a very efficient tool to finance the external trade deficit of the current account of the host 
country, especially for the developing countries, where the deficit from foreign trade is high and often problematic (Demekas, Horváth, Ribakov, and Yi Wul; 2005)

In the past two decades, FDI have become very important in developing countries. Multiple economic theories have identified a number of ways in which inflows of FDI can bring benefits to host countries. Many of these theoretical ideas have been proven in practice in many countries, but still many of these theories remain unproven from the overall conceptual point of view and in particular in certain regional countries. However, almost all studies linking FDI to GDP growth are concentrated in the aggregate effects of the impact of FDI on the economic growth of countries (Khaliq and Noy, 2007). So in this context, FDI are a factor of the productivity of a country's economy.

When we talk about the productivity factors it is recognized that the main factor of productivity is capital. Policies that encourage investments have a positive impact on the proven productivity in terms of medium and long term (Isaksson, 2007). The first studies of the analysis of factors productivity in the context of economic theories were developed by: Solow (1957) on the factors total productivity; Schultz (1961) on human capital; Arrow (1962) on the theory of "endogenous" domestic growth; Nelson and Phelps (1966) on the absorbing capacity; Abramowitz (1986) on the transfer of technology; Chenery and Syrquin (1988) on structural changes; etc. However in the context of measurable econometric analysis, the evaluation of productivity has known an expansion after the 90's. The literature on productivity is very broad and dynamic on the approaches toward productivity and the correlation of the factors between them. In their study Keller and Yeaple (2003) stated that there is a statistically stable and positive between FDI and productivity growth. They also analyzed the fastest spread of FDI in a sector of the economy is closely related with the implementation of new technologies. By supporting the fact that FDI affect positively the growth of productivity. Griffith, Redding and Simpson (2003), analyzed the dynamics of productivity growth in production in the UK for the years 1980-1992, and analyzed the role of foreign investors of multinational corporate. They focused on two mechanisms through which the inflows of FDI can affect either the level productivity growth or the scale of domestic productivity. The level of productivity growth comes as a result of new technology brought by FDI, while the growth of domestic productivity is due to the fact that FDI increase the internal competitiveness of the market and expansion of the markets to the point of becoming international.

The last few years developed also a theoretical approach which says that there are cases that FDI affect negatively a country's economic growth. This phenomenon has occurred in small economies of developing countries, which are influenced by foreign investors with large capital that often led to abuse due to their dominant position in the market. Large investors spread their activities in these countries, being able to win large tenders from the governments of the host countries and the latter use these investments for political positions. In turn, these investors, thanks to the support of the governments of the host countries, often in aggressive way they use the transfer of prices to minimize their tax liabilities. There are other critical opinions among experts of economy on FDl's, according to whom these investments affect in an unstable increase of the balance of payments flows as a result of inflow of capital in the beginning and then a series of profit outflows or repatriation of capital. This kind of problem becomes overtime more evident by putting to risk the vulnerable economies of the host countries themselves when these outflows are a result of financial problems of the headquarter companies (Lehman, 2002; Lehman and Mody, 2004).

In the context of numerous studies in the field of FDI, the literature suggests that the level of benefits from FDI is more considerable than their costs for a host country. It is also the basic reason why many developing countries have it as a government priority the growth of FDI in their country. The positive effects of FDI are particular for the economies in transition and in developing countries. The necessity for comprehensive restructuring and modernization of private enterprises and resources, or limited internal capacities, inevitably creates an environment for benefits from foreign investors. However, in developing countries often it is hard for researchers the measurement of the effect of FDI on economic growth, Isaksson (2007). This, for two reasons: (1) the host countries meaning the beneficiaries are in a very weak economic structure in absorption of these capacities, and (2) the quality of the data obtained for study in these countries is low or with problems.

Based on that what was expressed above, the purpose of our paper is to find the relation between the flow of FDI with the economic growth (GDP) in Albania, according to the Solow model but with the modifications of this model made by Romer $(1986,1990)$. Such an analysis is not done yet for the economy of Albania neither by local authors nor foreign scholars. 
Referring to official statistics in Albania, the level of time series related to FDI flows it is limited in time and in space. In the absence of sectoral classification of time performance of the flow of FDI, this paper will analyze the relationship of total flow FDI in GDP level. The data represent a time series of 1996-2013 with a period of 3-month for Albania. So, the econometric analysis will have as an object the short-term and long-term analysis of these connections.

\section{B. Analysis of the Herfindal - Hirschman index for FDl's in Albania}

Initially, FDI flows in Albania have been the consequence of the privatization process of state-owned enterprises, from small and medium to industrial and strategic, since 1992-2005 (eg banking, telecommunications, energy, hydrocarbons, mining, etc. ) (METE, 2011). As from 2005 onwards, overall FDI inflows are investments in private businesses. An overview of the performance of the stock of FDI in Albania, according to the years 2007-2013 (the data series of official publications) is given in the table below:

Table 1: Trend of the total stock of FDI, 2007-2013

\begin{tabular}{|l|l|l|l|l|l|l|l}
\hline & 2007 \\
$\begin{array}{l}\text { The stock of FDI (in million } \\
\text { Euro) }\end{array}$ & 1,830 & 2008 & 2009 & 2010 & 2011 & 2012 & 2013 \\
\hline
\end{tabular}

Source: Bank of Albania, publications until 2015.

Albania, as much favored by geographical position for trade exchanges, when it comes to territorial space of communication of the markets between them and the number of residents is in disadvantage (according to official sources there are about 2, 821, 977 habitants in Albania1). According to past and current practices, usually small countries do not manage to attract multinational corporation and industries which produce for export markets of a higher level of activity. However, the attractive aspect of FDI in our country relies heavily on the labor market's potential (eg labor market costs), also known as the phenomenon of "Fason industry". But the biggest partners in trade of our country such as Italy and Greece, are currently in a difficult economic situation, which puts into question the strategic development of investments from these countries of origin.

According to the opinion of the experts, FDI in Albania play an important role in many aspects of economic development of the country. These investments should be viewed as economic resource that can meet not only current needs, but even more the strategic ones. Currently about $80 \% 2$ of the FDI flow in Albania is an investment in share capital, the focus of foreign investors in our economy is in the following sectors: banking system; transport, commerce and telecommunications; energy and hydrocarbons; in the extractive industry; in the light industry of Fason production; construction and construction materials. While it remains a challenge attracting FDI in: agriculture and agribusiness; tourism; mining industry (not only extractive); hydrocarbons; etc.

However, to identify the focus of the stock of FDI by economic activity in Albania for the past two years according to official data (2012-2013), we built the graph in Figure Nr. 1, where you can see that the focus of foreign investors in Albania is in the activities of: (1) financial intermediation, (2) transport, storage and communication and (3) the extractive industries. 
The annual stock of FDI in Albania by economic activity (in millions of Euro)

Health and social work

Extra-territorial organizations and bodies

Other manufacture

Hotels and restaurants

Construction

Wholesale and retail trade; repair of.

Real estate, renting and business activities

Mining and quarrying

Financial intermediation

Transport, storage and communication

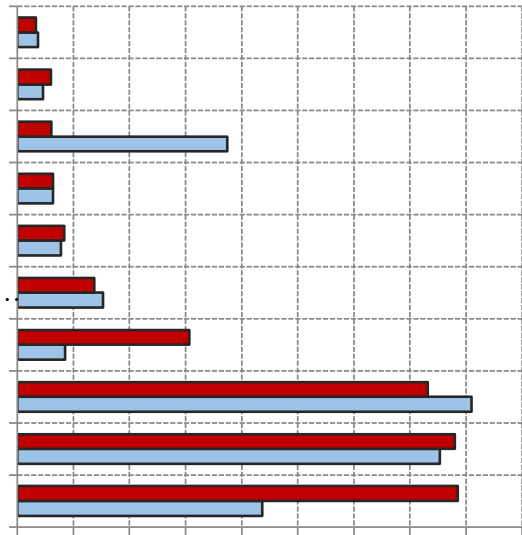

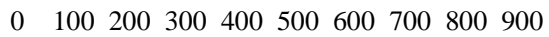

Source: Calculations by the authors with data from publications, the Bank of Albania 2015.

Figure no. 1: The performance of the stock of FDI by economic activity in Albania, 2012-2013.

In order to identify the focus of the stock of FDI in Albania by countries of origin of foreign investors for the past two years according to official data (2012-2013), we have built the graph in Figure Nr. 2, where you can see that the countries of origin with the highest level of stock of FDI in Albania are: (1) Greece (2) Canada and (3) Austria.

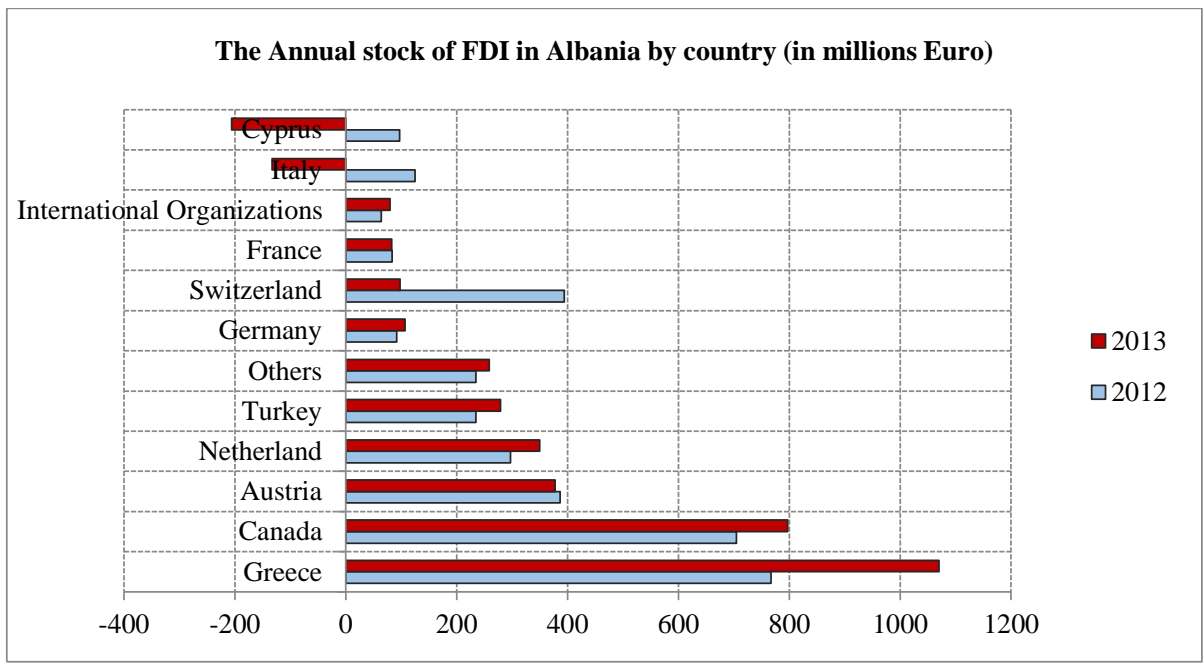

Source: Calculations by the authors with data from publications, the Bank of Albania 2015.

Figure no. 2: The trend of the stock of FDI in Albania, by countries, 2012-2013. 
One way of analyzing the unequal distribution of FDI (or concentration of FDI) is the use of Herfindal - Hirschman index (S. Ledyaeva and M. Linden, 2006). This index will be used to show the distribution of the stock of FDI in Albania. Herfindal Index - Hirschman Index (HHI) is given by the formula:

$$
\mathrm{HHI}=\sum_{\mathrm{j}=1}^{\mathrm{k}}\left(\frac{\mathrm{IHD}_{\mathrm{j}}}{\mathrm{IHD}} \cdot 100\right)^{2}
$$

Where: $I H D_{j}$ is the level of the stock of FDI by country of origin of the investor $j$ or by economic activity $j, F D I$ is the level of total annual stock of $F D I$ and $k$ is the number of countries or economic activities in our research (as shown in Figure no. 1 and Figure no. 2 above). The $H H I$ calculation is made for the time frame $2007-2013$, where the result obtained as in Figure no. 3:
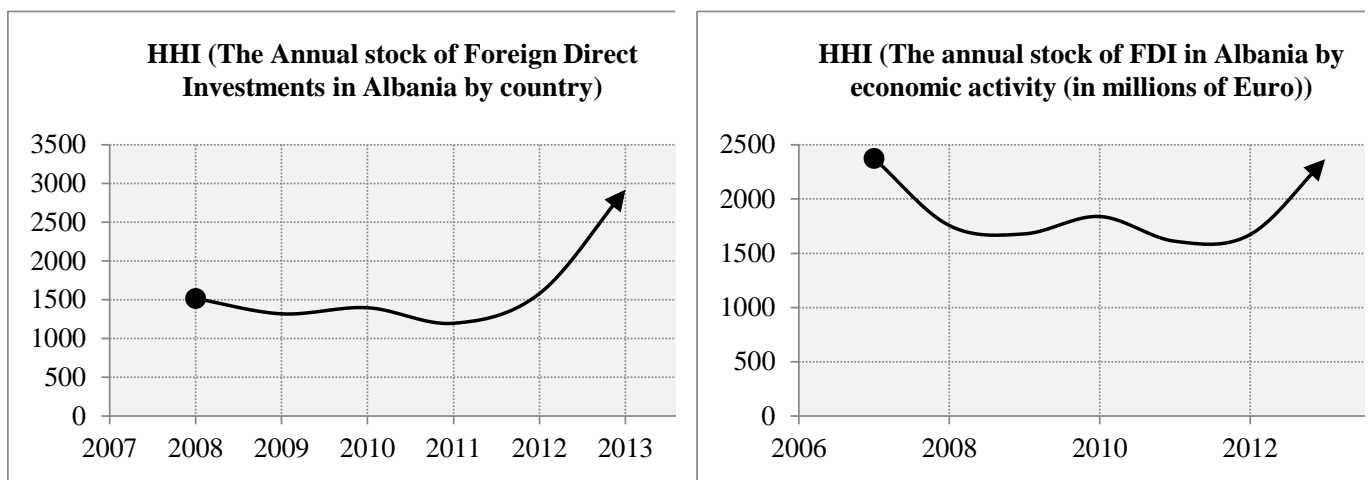

Source: Calculations by the authors with data from publications, the Bank of Albania 2015.

Figure no. 3: HHI for Albania by countries and economic activities, 2007-2013.

According to this index you can see that after 2010 there is a high tendency of concentration of the stock of FDI in Albania in a few countries of origin. This shows that the attraction of foreign investors in Albania is concentrated in a few countries, so the real competitive advantages of Albania in attracting foreign investors from different countries of the world are in decline.

If you look at the value of $\mathrm{HHI}$ by the distribution of the stock of FDI in economic activities in Albania, there is a consistency of concentration of the stock of FDI for the years 2007 - 2013 (except for 2007 and 2013 with higher concentration than other years). But how should this stability be seen, as a positive or a negative fact? If we look at the index's value for 2010 , it shows an average value of it, this means that we can use this as the base year in our analysis. To answer the question whether the $\mathrm{HHI}$ stability in Albania by economic activity is a good indicator or not, logically we should know how it was in 2010 in view of the distribution of FDI by economic activity. According to the Ministry of Economy (Annual Report, FDI, 2010) it is emphasized the fact that FDI should be absorbed to develop economic sectors such as business services, agriculture and agribusiness, mining and heavy industry, energy, tourism, because the levels are much lower than what was expected.

So 2010 is characterized by a concentrated distribution of the stock of FDI in a few economic sectors in Albania, it means that according to $\mathrm{HHI}$ the entire time frame of 2007-2013 has the same characteristic as the year 2010. Therefore, the sustainability of the $\mathrm{HHI}$ of the stock of FDI in Albania by economic activity shows that some sectors do not offer real competitive advantages in attracting foreign investors. 


\section{Analysis of FDI in Albania, according to the Solow model}

The methodology and data: In his opinion neoclassical Solow (1957) argued that economic growth is an "output" that positively influenced by "input" such as technology, capital, labor, or a vector of variables additional economy (such as imports, exports, institutional dummy variables, etc. ). This connection is determined by the following equation:

$Y=A \varphi(K, L, \Omega)$

Where: $\quad Y=$ the total output, or GDP (or growth),

$\mathrm{K}=$ capital investment,

$L=$ work (labor force),

$A=$ efficiency of production (the constant of model),

$\Omega=$ vector of additional variables.

Findlay (1978) developed more Solow model assuming that the growth rate of technological distribution is an increasing function of FDI, reclassifying the "input" with foreign capital and "input" with domestic capital. He argued that the growth of foreign capital increases internal capital. According to the internal growth models, technological changes in the production process, internal growth models "endogenous" are applied to see the effect of FDI on economic growth of a host country (Romer, 1986). Based on the Cobb-Douglas function, it follows that the Solow model has the form:

$Y=A^{*} K^{\alpha *} L^{\beta *} \Omega^{Y}$

By logarithmic transformation of the above equation, we get the form:

$\operatorname{Ln} Y_{t}=\operatorname{LnA}+a L n K_{t}+\beta L n L_{t}+\gamma L n \Omega_{t}+\varepsilon_{t}$

Where $\alpha, \beta, \gamma$ are respectively elasticity of: $Y$ (economic growth or GDP) related to capital (divided into two parts: in the capital of FDI and domestic investment DI), $L$ (labor cost, so the average salary or the number of employees), auxiliary variables $\Omega$ (qualitative variables "dummy" indicator technology, foreign trade, no. of population, etc. ) depending on the time " $t$ ". With $\varepsilon_{t}$ stated term error model that incorporates all factors that are not included in the model.

In this analysis it aims to explain the relation of capital (foreign direct investment and domestic investment) and labor (the average monthly wage) gross domestic product. The data represent a time series from 1996-2013 with 3-month period for Albania. To identify links explanatory variables and the importance and usefulness of their connection, this analysis consists in finding connections for use predictions for economic purposes.

Table 2: Economic variables and their description

\begin{tabular}{l|l|l} 
Variables & Description of the variable & Source of data \\
\hline GDP & Gross Domestic Product (value in million ALL). & INSTAT, 2014 \\
\hline FDI & $\begin{array}{l}\text { Foreign Direct Investment (values in million ALL), assesses } \\
\text { the impact of foreign capital in the economy of the host } \\
\text { country. }\end{array}$ & Bank of Albania, 2014 \\
\hline ID & $\begin{array}{l}\text { Albanian capital investments (value in million ALL), assesses } \\
\text { the impact of domestic capital in national production. }\end{array}$ & Bank of Albania, 2014 \\
\hline L & The average monthly wage (value at ALL). & INSTAT, 2014
\end{tabular}

Source: Review of literature by authors. 
The statistical results of the model: doing testing program EViews 7 for Solow model, the case of Albania, we get statistical results in Table 3, below:

Table 3: Results of statistical significance of the dependent variable log (GDP)

\begin{tabular}{lllll}
\hline \hline Variable & Coefficient & Std. Error & t-Statistic & Prob. \\
\hline \hline C & 1.297673 & 0.642820 & 2.018718 & 0.0475 \\
LOG(IHD) & 0.032184 & 0.011606 & 2.773042 & 0.0072 \\
LOG(ID) & 0.532712 & 0.037289 & 14.28607 & 0.0000 \\
LOG(PAG) & 0.469908 & 0.053546 & 8.775720 & 0.0000 \\
\hline
\end{tabular}

Source: Calculations on EViews 7, by the authors.

Even in the case of Albania, the Solow model shows a statistically significant relationship and positive dependent variable $\log (\mathrm{GDP})$ with independent variables: $\log (\mathrm{FDI}), \log (\mathrm{ID})$ and $\log (\mathrm{L})$. As you can see, this model assesses the relative degree of responsiveness of GDP or its elasticity with respect to the dependent variables:

$\log \left(G D P_{t}\right)=1.297673+0.032184^{*} \log \left(F D I_{t}\right)+0.532712^{*} \log \left(I_{t}\right)+0.469908^{*} \log \left(L_{t}\right)+\varepsilon_{t}$

So the model is statistically significant by Fisher test, with statistical significance level of $5 \%$ and the adjust coefficient of determination is $87.73 \%$. This coefficient shows a very high level of explanation links economic indicators as independent variables in the effect on the dependent variable, GDP. Referring to the model, the coefficients of independent variables in the model, show the effect of the change in percentage of GDP, when variables grow by $1 \%$ in the conditions "ceteris paribus".

The constant of the model is statistically significant and expresses the average of the 3-month rate of growth of GDP from 1996 to 2013, on the basis of 3 months, which means the technological level of Albania.

According to the model, if FDI will rise by $1 \%$, it will have a positive effect on GDP growth only $0.03 \%$, while much larger is the effect they have IDs, where if IDs increased by $1 \%$, they will have a positive effect on GDP growth of $0.53 \%$. The same conclusion we receive for the level of the average wage, if $L$ will increase by $1 \%$, will have a positive effect on GDP growth of $0.47 \%$. As we said above, the time period 1996-2005 was not clean FDI investment in new businesses, but as a result of privatization, and after 2005 they have dominated more inflows of FDI into new businesses. This explains why the direct effect is several times smaller by FDI than domestic investment. However, FDI has had a significant impact on employment, the number of employees (particularly fason industry), which increases "endogenous" employment and economic growth. In Albania, one of the markets more informal, accepted by the IMF and World Bank (2013) is the employment market, therefore variable labor (average salary) is an indication that there is a high margin of error in the official statistics and it makes measuring the effect impossible for "endogenous" FDI in average salary.

But to use this model to obtain evaluation results with high statistical reliability, the effects of linking economic variables in the future, model is the subject of a set of econometric tests that prove the usefulness of using the model, according to the explanatory parameters derived from the data analyzed. This means that should satisfy all the basic assumptions of Theorem Gauss-Markov (Alexander Ludwig and Klaus Schmidt, 2010). Table 4, below reflects the type of test and the result for our model:

Table 4: Results of econometric tests, for an efficient model 


\begin{tabular}{|c|c|c|}
\hline Denomination Test & The explanatory description & The result \\
\hline $\begin{array}{l}\text { Functional forms, test- } \\
\text { RESET }\end{array}$ & $\begin{array}{l}\text { This test shows if the form of the model is } \\
\text { appropriate (that is completely flexible or } \\
\text { semi-flexible) }\end{array}$ & $\begin{array}{l}\text { The right form is fully the elastic function for } \\
5 \% \text { significance level. }\end{array}$ \\
\hline $\begin{array}{l}\text { Multicollineritety, VIF- } \\
\text { test }\end{array}$ & $\begin{array}{l}\text { This test shows if there is a correlation } \\
\text { between independent variables included in } \\
\text { the model. }\end{array}$ & $\begin{array}{l}\text { There is multicollinearity but it is not perfect } \\
\text { (since the variables are statistically } \\
\text { significant, we have not made the } \\
\text { elimination of any variable). }\end{array}$ \\
\hline $\begin{array}{l}\text { Heteroskedasticity, } \\
\text { White-test }\end{array}$ & $\begin{array}{l}\text { This test shows the absence of connectivity } \\
\text { residues constant variance model with } \\
\text { population data. }\end{array}$ & $\begin{array}{l}\text { No heteroskedasticity (logarithmic form } \\
\text { eliminates it) }\end{array}$ \\
\hline $\begin{array}{l}\text { Autocorrelation, LM- } \\
\text { test }\end{array}$ & $\begin{array}{l}\text { This test shows the serial correlation of } \\
\text { independent variables and } \varepsilon \text { model residues. }\end{array}$ & $\begin{array}{l}\text { There is autocorrelation but it eliminated by } \\
\text { adjusting the model with AR (1) and } \\
\text { coefficient of about }+0315 \text {. }\end{array}$ \\
\hline $\begin{array}{l}\text { Normal distribution of } \\
\text { residues }\left(\varepsilon_{t}\right), J-B \text { test } \\
\text { Source: Ćalculations on É É }\end{array}$ & $\begin{array}{l}\text { The model is tested If residues are normally } \\
\text { distributed or not. } \\
\text { lews } 7 \text {, by the authors. }\end{array}$ & 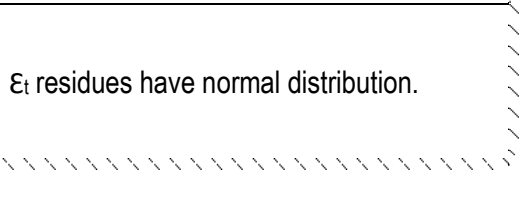 \\
\hline \multicolumn{3}{|c|}{$\begin{array}{l}\text { Results of econometric tests from Table 4, support the argument that our model estimated with its parameters above, it is } \\
\text { right to explaining the dependent variable GDP changes of independent variables arising at the level of foreign direct } \\
\text { investment, domestic investments and the average wage level. }\end{array}$} \\
\hline \multicolumn{3}{|c|}{ Table 5: results of the Wald test for long-term connection to the model } \\
\hline Test Statistic & Value & Probability \\
\hline F-statistic & 170. 2908 & 0.0000 \\
\hline Chi-square & 510.8724 & 0.0000 \\
\hline
\end{tabular}

Null Hypothesis: $C(2)=C(3)=C(4)=0$

Null Hypothesis Summary:

\begin{tabular}{lll}
\hline \hline Normalized Restriction $(=0)$ & Value & Std. Err. \\
\hline \hline $\mathrm{C}(2)$ & 0.032184 & 0.011606 \\
$\mathrm{C}(3)$ & 0.532712 & 0.037289 \\
$\mathrm{C}(4)$ & 0.469908 & 0.053546 \\
\hline \hline
\end{tabular}

Source: Calculations on EViews 7, by the authors. 
By Wald test, the table 5 above, our model of multiple regression is statistically significant, with the level of importance $p$ $<5 \%$, this means that the model can also be used for long-run economic analysis. So, the impact of FDI on the growth of GDP is not only in the short-run but it is sustainable and in the long-run.

\section{Conclusions and Recommendations}

FDI flows in Albania began after 90s, which for more than a decade, were in the form of privatization of state-owned enterprises, while after the year 2004-2005, these flows were generally the capital investment in businesses. According to the analysis of Herfindal-Hirschman index, the stock of FDI in Albania in 2007-2013, is focused on activities such as: financial intermediation, transport and telecommunications and mining industries. While agriculture and agribusiness, tourism, mining industry (non-extractive) continues to be not preferred by foreign investors. Even the origin of foreign investors is concentrated in a few countries of origin, led by Greece, Canada, Austria, the Netherlands, Turkey and Italy. So, government authorities should mitigate this concentration trend of FDI by promoting also other sectors of the economy, even by putting together a package of additional facilities with regulatory nature (legal), contractual and fiscal.

According to econometric analysis of the model in our paper, it resulted in a statistically significant relation of GDP to FDI, domestic investment and average salary. Indicating that (ceteris paribus conditions), when:

FDI increased by $1 \%$, GDP will grow by $0.03 \%$,

investments in domestic capital will increase by $1 \%$, GDP will grow $0.53 \%$,

aggregate average wage will increase by $1 \%$, GDP will grow $0.47 \%$.

By using Wald test, with a statistical significance level of $p<5 \%$ turns out that the model parameters are stable and have simultaneous effect in the long run.

The elasticity level of the GDP to the explanatory variables is different, but according to the model, the greatest impact on GDP comes from domestic capital investments, then from the average wage. While FDI have an impact several times smaller than the Albanian capital investments. This happened for several reasons:

First, the level of investments from Albanian capital (private and public) from 1996 to 2005 had an average weight of 11.5 times higher than FDI, and from 2006 to 2013 had average weight about 5 times larger than FDI. Over the recent years it is observed that the reduction of the share of investment with domestic capital has come as a result of their declining rate that was higher than the declining rate of FDI.

Secondly, FDI in Albania have had a positive impact on the employment rate, in the number of employees (especially with the Fason products), affecting in an "endogenous" way in the employment growth and the latter in economic growth itself. But due to high informality levels in the labor market and the absence of official data, it is impossible to measure the effect of "endogenous" FDI in average salary.

Thirdly, FDI are absorbed from privatizations and concessions during their contracted duration, or a natural resource, adding a low value in the economy. This in return indicates that the Albanian institutions have shown weakness in the achievement of their objectives. Succumbing to secret corrupted agreements, or showing inefficiency of infrastructure for evaluation and control of investments in the country. In these conditions, it would be better to orient the investment focus on domestic capital initiatives.

Also a significant problem in Albania is the lack of detailed official statistics, because of missing time series for various study purposes, especially in the real economy. This led to the limitation of our model's variables. In this context, we suggest to the Institute of Statistics and various other institutions in Albania, to create a database for all researchers, policy and project makers, expert evaluators, etc. 


\section{References}

[1] Abramowitz, M. (1986); Catching Up, Forging Ahead, and Falling Behind. Journal of Economic History, Vol. 46, pp. 385-406

[2] Arrow, K. J. (1962); The Economic Implications of Learning by Doing. Review of Economic Studies, Vol. 29, pp.

[3] Bank of Albania (2005); Foreign direct investment in developing countries of Eastern Europe: The Case of Albania.

[4] Bank of Albania (2012); Foreign Direct Investment Report, 2011.

[5] Bevan, A. A. , \& Estrin, S. , (2004); The determinants of foreign direct investment into European transition economies. Journal of Comparative Economics, pp. 775-787.

[6] Brooks, C. (2008); Introductory Econometrics for Finance (ed. Il ed. ). Cambridge: Cambridge University Press.

[7] Candela, R. A. (2009); "Less Developed Countries, Tourism Investment and Local Economic Development". Bologna, Italy.

[8] Chenery, H. \& Syrquin M. C. (1988); "Patterns of Structural Change", in H. B Chenery and T. N. Srinivasan (Eds. ), Handbook of Development Economics, Amsterdam: North-Holland, pp. 203-73

[9] Demekas, D. G. , Horváth, B. , Ribakova, E. , \& Wu, Y. , (2005); Foreign Direct Investment in Southeastern Europe: How (and How Much) Can Policies Help? IMF Working Paper.

[10] Demeti A. \& Rebi E. (2014); Foreign direct investments (FDI) and Productivity in Albania. Interdisplinary Journal of Research and Development; "Alexander Moisiu" University, Durrës, Albania. Vol (I), No. 1, 201

[11] Demirhan, E. , \& Masca, M. (2008); Determinants of Foreign Direct Investment Floës to Developing Countries: A Cross-Sectional Analysis. Prague, Economic Papers, 356-369.

[12] Dougherty C. (2007); Introduction to Econometrics. Third edition, Oxford press.

[13] Estrin, S. , \& Uvalic, M. , (2013); Foreign direct investment into transition economies: Are the Balkans different?

LSE 'Europe in Question' Discussion Paper.

[14] European Commission (2009); The Ëestern Balkans in Transition. Occasional Papers No 46.

[15] Fortanier, F. (2007); Foreign direct investment and host country economic growth: Does the investor's country of origin play a role?

[16] Griffith, R. , Redding, S. \& Simpson H. (2003); Productivity Convergence and Foreign Ownership at the

Establishment Level. Discussion Paper No. 572, London: Centre for Economic Performance

[17] Grosse, R. , \& Trevino, L. J. (2005); Neë Institutional Economics and FDI Location in Central and Eastern Europe. Management International Revieë, Vol. 45, No. 2. Pp. 123-145.

[18] Hejazi, W. , \& Pauly, P. , (2002); Foreign Direct Investment and domestic capital formation. Industry Canada Research Publications Program, Working Paper Number 36.

[19] IMF Country Report No. 13/7, (2013); "Albania 2012, Article IV Consultation".

[20] Isaksson A. (2007); Determinants of Total Factor Productivity: A Literature Review. United Nations Industrial Development Organization

[21] Isotalo J. (2007); Linear estimation and prediction in the general Gauss-Markov model. Academic dissertation.

[22] Khaliq and Ilan Noy (2007); Foreign Direct Investment and Economic Growth: Empirical Evidence from Sectoral Data in Indonesia.

[23] Keller, W. \& Yeaple S. R. (2003); Multinational Enterprises, International Trade, and Productivity Growth: FirmLevel Evidence from the United States. NBER Working Paper No. 9504, Cambridge, MA: NBER

[24] KPMG Albania Sh. p. k. (2011); Investment in Albania.

[25] Ledyaeva, S. , \& Linden, M. , (2006); Foreign direct investment and economic growth: Empirical evidence from Russian regions. BOFIT Discussion Papers.

[26] Lehman, A. , \& Mody A. (2004); International Dividend Repatriations. IFM Working Paper 04/5

[27] Ludwig A. and Schmidt K. (2010); Calendar Year Reserves in the Multivariate Additive Model. 
[28] Majocchi, A. , \& Strange, R. (2007); The FDI location decision: does liberalization matter?

[29] Navaretti, G. B. , \& A. J. Venables (2004); Multinational Firms in the World Economy.

[30] Nelson, R. \& E. Phelps (1966); Investment in Humans, Technological Diffusion, and Economic Growth. American Economic Review, Vol. 56, pp. 69-75

[31] OECD (2008); Benchmark Definition of Foreign Direct Investment. Fourth edition.

[32] Pournarakis, M. , \& C. Varsakelis, N. (2004); Institutions, internationalization and FDIs: the case of economics in transition. Transnational Corporations, Vol. 13 (No. 2), 78-94.

[33] Romer, P. (1986); Increasing Returns and Long Run Growth. Journal of Political Economy, Vol. 94, pp. 1002-37

[34] Romer, P. (1990); Endogenous Technological Change. Journal of Political Economy, Vol. 96, pp. S71-S102

[35] Schultz, T. W. (1961); Investments in human capital. American Economic Review, Vol. 51, pp. 1-17

[36] Shahini, B. , Mustafaj, I. , \& Rexhepi, P. (2009); The linkeage between politics and investment: How do they help each other?

[37] Solow, R. (1957); Technical Change and the Aggregate Production Function, Review of Economics and Statistics, Vol. 39, pp. 313-20.

[38] Uvalic, M. , (2006); Trade in Southeast Europe - recent trends and some policy implications. The European Journal of Comparative Economics Vol. 3, n. 2, pp. 171-195.

[39] Vesaite, R. (2014); FDI from European Union to Western Balkan countries: is the economic development being intensified in the region?

[40] Wacker, K. (2011); The Impact of Foreign Direct Investment on Developing Countries' Terms of Trade.

[41] World Bank. (2013); Economy Profile for Albania: "Doing Business 2013".

[42] World Bank. (2012); Report on Foreign Direct Investment in Albania, 2011. 